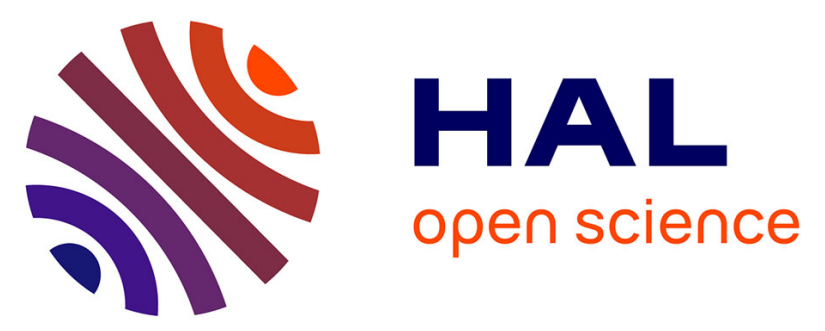

\title{
Between Bureaucracy and Market: Chinese Industrial Groups in Search of New Forms of Corporate Governance
}

Jean-François Huchet, Xavier Richet

\section{- To cite this version:}

Jean-François Huchet, Xavier Richet. Between Bureaucracy and Market: Chinese Industrial Groups in Search of New Forms of Corporate Governance. Post-Communist Economies, 2002, 10.1080/14631370220139918 . hal-01331919

\section{HAL Id: hal-01331919 \\ https://hal-inalco.archives-ouvertes.fr/hal-01331919}

Submitted on 14 Jun 2016

HAL is a multi-disciplinary open access archive for the deposit and dissemination of scientific research documents, whether they are published or not. The documents may come from teaching and research institutions in France or abroad, or from public or private research centers.
L'archive ouverte pluridisciplinaire HAL, est destinée au dépôt et à la diffusion de documents scientifiques de niveau recherche, publiés ou non, émanant des établissements d'enseignement et de recherche français ou étrangers, des laboratoires publics ou privés. 


\title{
Between Bureaucracy and Market:
}

\section{Chinese Industrial Groups in Search of New Forms of Corporate Governance}

\author{
Jean-François Huchet, \\ University of Rennes 2 and China Centre EHESS, Paris \\ juhuchet@wanadoo.fr \\ $\&$ \\ Xavier Richet, \\ OEP, University of Marne la Vallée, France \\ richet@univ-mlv.fr
}

Published in

Journal of Post-Communist Economies, Vol.14, n², 2002, pp. 170 - 201. 


\begin{abstract}
This paper investigates the peculiar and contradictory nature of the on-going construction of a system of corporate governance in China. The analysis attempts to overcome the limits of traditional corporate studies that tend to focus on enterprise management, and puts the issue within the framework of the systemic and political relationships that shape economic management and state intervention in large enterprises in transitional socialist systems. The emergence of a specific managerial culture within the market and of winners among the enterprises is related to the position still held by the state in the enterprise asset, and by the access to competitive markets available to the enterprises. State owned enterprises, enjoy the protection of their status but they are more successful and adopt a more profit-oriented management culture if they operate in the internationalised and competitive markets rather than in the strategical lowprofit, state-dominated sectors. Due to continuous interaction between enterprise management and external (policy or macro-economic) factors, and to the absence or underdevelopment of most of the institutions generally necessary for a sound corporate governance system (financial markets, bank independence, free press etc.) the privatisation does not seem sufficient to engender all round market-led governance.
\end{abstract}


China's transition was for a long time presented as a counter-example of the transitions undergone by the countries of Eastern Europe. The virtues of Chinese-style gradualism were put forward in opposition to the pernicious effects of the shock therapy applied in most Eastern European economies and in the former Soviet Union (P. Boone, et al., 1998). Nevertheless, after hesitating for a long time, the Chinese authorities today have to go right to the heart of the matter in the transformation of post-socialist economies. More concretely, the task that lies ahead for them is to promote the emergence of a more effective system of corporate governance than that inherited first from the Maoist and then the Deng Xiaoping period. Taking as a definition of corporate governance "the set of mechanisms governing the decisions of leaders and defining their discretionary space" (G. Charreaux, 1997), we can easily grasp why reforms in this area are henceforth a priority for the future of the Chinese economy. Phenomena such as the duplication of under-sized investments (J.-F. Huchet, 1999), endemic corruption (J. Andrieu, 1996, Q. He, 1998, J. Kwong, 1997, B. Liu and P. Link, 1998) and the stripping of State assets (Y. Cao, et al., 1998, X.L. Ding, 2000, Q. He, 1998), things which have all been broadly studied, show to what extent the control mechanisms operating on the decisions of those who hold the power in firms have either been non existent or particularly ineffective in the great majority of Chinese firms. Their consequences have assumed such proportions, especially with the rapid rise of non performing loans in the banking sector (N.R. Lardy, 1998) that, at the time of the Asian crisis, and for the first time since the start of the reform process in 1978, they have left up in the air the possibility of a systemic type crisis similar to the one recorded in other Asian countries.

From this perspective, the Asian crisis have played a beneficial role for China by acting as 
an electro-shock for the Chinese leaders, who, sheltered behind a non-convertible yuan, rushed to set up a series of reforms designed to improve corporate governance more or less directly. These very ambitious reforms can be compared to those applied in the countries of Eastern Europe following the collapse of the Communist regimes in the early 1990s (X. Richet, 1992): the restructuring of State-owned enterprises, the privatisation of small to medium-sized State-owned and collective urban enterprises, the complete reworking of the banking and financial system, the setting up within firms of boards of directors and supervisory councils, a legal code for companies, laying out the principles of protection for minority shareholders, the rejigging of the administrative system for managing the State's assets, and finally, the completion of negotiations on China's entry into the World Trade Organisation (WTO) (H. Broadman, 2000).

In spite of the scope of such reforms, there remain many questions on their ability to improve Chinese corporate governance. A first series of questions relate to how administrativetype reforms in the State assets management system, such as those that have been implemented since 1994 and which make only very partial modification to the power structure in the Stateowned enterprises, will be able to contribute to improving the system of corporate governance in these firms? A second series of questions concerns the inter-relation between the internal control mechanisms and those that are external to firms. That is, whether privatisations (partial or total) and the measures introducing the traditional instruments of corporate governance (such as boards of directors and supervisory boards), will be enough, while a great number of basic mechanisms of external control (the financial market, the independence of banks, a free press, respect for the rights of minority shareholders) are still absent or largely deficient. Finally, a third series of questions that are more general in nature, but just as crucial, make us wonder if a profound 
transformation of the control structures acting on firms (a clearly announced objective of the reforms) is compatible with the Chinese Communist Party (CCP) continuing its monopoly over the political and economic life of the country? To try to answer these questions, we will first set out very briefly the main factors influencing corporate governance in China (section 1). We will then draw up a typology of the various categories of industrial groups that have emerged since the beginning of the reform process, at the same time as assessing, for each category, the impact on their corporate governance of recent reforms and the forthcoming entry of China into the WTO (section 2).

\section{1 - Fundamental factors of corporate governance in China}

Several more or less closely interrelated mechanisms are in a position to influence the nature and functioning of corporate governance in any given economy. Besides the formal mechanisms of corporate governance that are to be found in all management school textbooks and which form the basis of the "agency theory" (M.C. Jensen and W.H. Meckling, 1976) - like the setting up and smooth running of a board of directors, supervisory boards, a general assembly of shareholders -, there is also a series of essential factors which reinforce the efficiency of these formal mechanisms or even supplant them. Chief amongst these are the degree of competition in the market place for goods and services, which remains one of the main elements for controlling the behaviour of managers; a healthy business ethic, the existence of a free press, pro-active consumer groups, a banking sector that works well, a judicial environment allowing minority shareholders to defend their rights, a labour market that promotes the reputation of company chiefs (and puts a brake on the search for returns). 
In the context of transition economies, the institutions supporting these various disciplinary mechanisms are often missing or under-developed. Public policies have sought, through various legislative measures, to create formal institutions for corporate governance (the corporatisation of State-Owned companies, the setting up of boards of directors, supervisory boards and shareholder meetings), yet without considering the importance of mechanisms that are outside the company. Several writers have shown how, in certain former socialist countries in transition, such legislation was in fact nothing more than pie in the sky (M. Aoki, 1995, J. Blasi, 1997, P. Boone, et al., 1998).

China is also subject to this phenomenon. Through a number of legal texts, principally the 1993 corporate law, followed by the 1998 securities law, complemented by a whole series of directives, China has, since the early 1990s, established all the formal institutions of corporate governance (for a more detailed study of all the provisions in the Chinese system, see C. Lin, 2000 or OECD, 2000). These reforms have been largely modelled on the current system in Germany, instituting shareholders' meetings, a board of directors, and more particularly, a supervisory board in which the company's employees are represented by law. In his study on corporate governance in China, C. Lin states that legal texts dealing with corporate governance are considerably more detailed in China than in the United States, which nonetheless, in terms of capitalist economies, embodies one of the oldest and most tried and tested systems of corporate governance (C. Lin, 2000). Despite such reforms, the elements we referred to in our introduction, namely the duplication of under-sized investments, endemic corruption at all levels of the administration as well as in companies, the stripping of State assets, which is still occurring on a grand scale, are a perfect illustration of the situation described in the transitional countries of 
Eastern Europe and Russia (E. Berglöf et R. Vaitilingam, 1999) concerning the interaction between the formal institutions of corporate governance and the control mechanisms outside the company.

Even if a good number of problems facing China are typical of socialist economies in transition, specific national factors that we have tried to detail for China in table 1-1, have a determining influence on the efficiency and possibilities for change in corporate governance in each country.

Table 1.1 : Factors influencing the corporate governance in China

\begin{tabular}{|c|c|}
\hline Positive factors & Sources of blockages and inefficiencies \\
\hline $\begin{array}{l}\text { Political Stability and a Political Agenda } \\
\text { Favouring the Reforms }\end{array}$ & $\begin{array}{l}\text { The politisation of the banking system and } \\
\text { soft budgetary constraint for State-owned } \\
\text { enterprises }\end{array}$ \\
\hline The Appearance of Competitive Force & $\begin{array}{l}\text { The Law on Bankruptcy rarely applied, } \\
\text { restructuring carried out by the authorities and } \\
\text { regional protectionism. }\end{array}$ \\
\hline $\begin{array}{c}\text { Monetary Policy, notable budgetary } \\
\text { tightening affecting State-owned } \\
\text { enterprises since } 1994 .\end{array}$ & $\begin{array}{l}\text { A Labour Market for Managers still under- } \\
\text { developed. }\end{array}$ \\
\hline \multirow[t]{3}{*}{$\begin{array}{l}\text { The export enhancement strategy and the } \\
\text { reception of direct foreign investment. }\end{array}$} & $\begin{array}{l}\text { Institutional and ideological blockages } \\
\text { affecting the private sector }\end{array}$ \\
\hline & $\begin{array}{c}\text { Excessive bureaucratic decentralisation of } \\
\text { economic power, corruption and preservation } \\
\text { of the political machinery's hold on power } \\
\text { over economic life }\end{array}$ \\
\hline & State of Law vs Rule of Law. \\
\hline
\end{tabular}

All these factors provide a reasonably adequate framework for analysing in general terms the main mechanisms of corporate governance in China and are well documented in the literature (Y. Qian, 1995; O.K. Tam, 1999; W. Woo, et al., 1997; C. Lin, 2000 or OECD, 2000). However, faced with the growing differentiation between Chinese enterprises, we have tried to refine the 
analysis and measure the impact of the recent reforms and China's entry into the WTO on the corporate governance for each major category of Chinese enterprises.

\section{2 . Differenciation and Evolution of Corporate Governance in Chinese firms}

\subsection{An Attempt at categorisation of Chinese firms}

The industrial organisation of the country is particularly heterogenous, both in terms of structures and control. Such heterogeneity is due firstly to historical reasons, predating the reforms, and linked to the strategy of industrial development decided by the leaders of the day and by the major political events that shook China (Great Leap Forward, break with the Soviet Leaders, Third Front Policy, Cultural Revolution) up until 1979. This resulted, on the one hand, in the establishment of a planned system of a conventional type, managed by the central government with a functional division into sectors, but concentrated on some major State industrial firms, and, on the other, in a semi-planned, semi-free market system, geographically partitioned off and controlled by the local authorities, in which there sprang up a host of Stateowned or collective small businesses. (C. Riskin, 1987).

The reform period up until the end of the 1980s did not give rise to any major disruptions in the control system, apart from in the even more marked geographic break-up of industrial structures (J.-F. Huchet, 1993). Despite the progressive disappearance of the Plan, the central government continued to exert its control over the major State-owned enterprises. For their part, local governments (often at the municipal and district level) became the de facto owners of the State and collective small businesses, after several waves of administrative decentralisation (D. 
Granick, 1990). Stimulated by a fiscal system allowing them to keep a large part of the income produced by small business, and taking advantage of a largely decentralised banking system and a promotion system for local political leaders based on an ability to develop economic activity, the local authorities became much more entrepreneurial. Various writers have shown (M. Blecher and V. Shue, 1996, S. Breslin, 1996, J. Duckett, 1998, J. Oi, 1998, J.C. Oi, 1995, A.G. Walder, 1995) how the local authorities have sought to develop a local industry that is as complete as possible in their area, yet without taking into consideration the waste of resources caused by the duplication of investments that are more often than not under-sized and operating under the umbrella of local protectionist policies. Thus, in the late 1980s, we find a differentiation among firms in their control methods linked rather to property rights and to a deconcentration of the Chinese administrative system than to any principal of efficiency derived from the market:

1 - Large State-owned enterprises run from the central government.

2 - Small to medium-sized businesses in the State and collective sector set up in urban areas and run by local governments.

3 - The rapid development of small firms in rural zones registered as collective enterprises and run by local governments.

4 - The emergence of private firms on the fringe of the centrally-planned system, especially in trade and services.

Since the late 1980s there has been a second source of heterogeneity, directly linked to the effects of the rise of competition in Chinese industry, even if it has been irregular across the 
various spheres of activity. In some sectors, particularly those in direct contact with end consumers (light industry, food production, textiles), competition has forced firms to implement reforms to adapt to the market. Some State-owned enterprises and rural collectives (see below category $n^{\circ} 3$ ), but equally private companies that have now reached a critical mass (category $n$ $\left.{ }^{\circ} 6\right)$, have developed aggressive commercial strategies aimed at increasing their market share, and have been able to modernise their equipment and management practices. The big losers in the reform process since the early 1990s are to be found among the State-owned and collective small and medium-sized enterprises in urban areas (category $\mathrm{n}^{\circ}$ ). Under-sized and under-capitalised, these firms are experiencing great difficulties and are only surviving thanks to the protectionist practices of the local authorities. Finally, we are witnessing the take-off of foreign firms operating on Chinese soil, some even having a dominant share of the internal market (telecommunications with Alcatel and Motorola, or Volkswagen in the automobile industry).

Thus, since the mid-1990s, the rise of competition has led to the emergence of new categories of Chinese groups with more complex control structures:

1 - The major financial holding companies in the public sector specialising in services (financial, transport, trade) dependent on the central or provincial government and with a subsidiary listed on the Hong Kong Stock Exchange, that are commonly called "Red Chips" (CITIC, COSCO, China Resources, Beijing Enterprise).

2 - The major State groups controlled by the central government and operating in protected sectors.

3 - The State sector and collective groups who are leaders in the competitive fields and 
who have earned a greater autonomy from their overseeing administration (mainly local administrations).

4 - The joint ventures, a majority of whose capital is controlled by a foreign company and the firms $100 \%$ controlled by foreign multinationals.

5 - Small groups in the State and collective sector controlled by local governments.

6 - Private groups in the competitive sectors that increasingly operate under the control of the main owner.

7 - Small private and family collective commercial firms in the service sectors in urban and rural areas.

We have left aside the categories 1,4 , and 7 that do not fit into the analytical field of this article. As far as collective rural firms go, it seemed to us difficult to group them together under the one banner, despite there being an abundant literature that regards them as a specific feature of Chinese economic development since the 1970's, and theorised by several economists under the concept of "hybrid" property rights (V. Nee, 1992, M.L. Weitzman and C. Xu, 1993, G. Jefferson, 1993, G. Jefferson, et al., 1994, L. Putterman, 1995, J. Oi, 1995, T.G. Rawski, 1995). Some firms that have since the early 1990s become major groups, such as Kelon, Chunlan, Dalian Bohai (which are now part of the country's top 100 groups), are in fact very close to the leading State-owned enterprises operating in the competitive sectors, and we have grouped them together in category $\mathrm{n}^{\circ} 3$. Furthermore, an important part of collective rural enterprises are composed of smaller-sized firms and is closer in terms of management practice to the urban State-owned and collective small and medium-sized companies run by local governments. On 
this account, we have grouped them together in category $n^{\circ} 5$. Finally, one part of the rural collective firms that is hard to assess has, since the mid-1990s, taken on the status of private enterprises. This phenomenon is particularly visible in the coastal provinces, where a considerable number of firms that had been formerly registered as collective firms, in order to benefit from the protection of the all-powerful local bureaucracy (the system of hongmao, literally, "red cap "), felt that the local public institutions had sufficiently changed to provide a guarantee of protection of private property (J. Oi, 1998, J. Unger and A. Chan, 1999). Even if this development is far from taking place in the inland provinces, some writers (W.T. Woo, 1998) maintain that it signifies the end of the supposed anomaly of the Chinese case. The "hybrid" property rights which characterise the rural collective enterprises may in fact merely reflect a transitional stage during which the economic players were seeking to secure their rights in a particularly uncertain political and economic environment. Similar configurations have, moreover, been largely studied in other countries in transition, notably in Hungary (D. Stark, 1997) before the evolution of the political situation, the development of competition and financial constraints facing firms brought about a rapid clarification of property rights (often to the benefit of the former nomenclatura).

It was relatively difficult given the available statistical lists to quantify the importance of the different categories of groups under discussion in our analysis. By cross-referencing series to the country's largest firms, we have partially tried to provide a few indications in table and figure $\mathrm{n}^{\circ} 2-1$ on turnover, profits and capital. Among the 100 largest industrial groups operating in China, category $\mathrm{n}^{\circ} 2$ of the major State-owned enterprises operating in non-competitive sectors is very clearly the most important. Of the leading 100 Chinese groups in 1997, 94 are State-owned 
enterprises (or ones in which the State has a controlling interest) operating in sectors with little competition and where there is a very high representation of firms linked to the petrochemical industry (34 firms), provincial public companies producing electricity (23 firms), or working in metallurgy (18 firms), and, more tangentially, in the tobacco and automobile industries. Another factor of note, and in spite of the willingness of the Chinese government to promote the private sector, is that there was no private group among the 100 biggest companies in China in 1997. From this point of view, Sino-foreign enterprises, particularly in the automobile industry (but in which the Chinese State maintains a majority stake) and telecommunications, represent what is now a non negligeable portion, and one that is undergoing rapid growth in turnover, profits and capital. Finally, 4 groups in the rural collective sector figured in the country's top 100 firms (Chunlan, Kelon, Dalian Bohai and Tianjin Yaoshun). Nonetheless, in the coming years, we should see other groups entering the top 100 Chinese companies, coming from either into the collective sector such as Legend (information technology) or the private one, like New Hope (in the food industry).

Table and Figure $n^{\circ} 2-1:$ The weight of different categories of firms among the top 100 operating in China in 1997 (unit: millions of yuan, except for the first column)

Sources : Zhongguo qiye guanli nianjian, 1997, 1998 (China's yearbook of enterprise management); Zhongguo xiangzhen qiye paixu, 1997 (Classification of Chinese rural collective firms); Zhongguo daxingqiye nianqian, 1997, 1996 (China's yearbook of major firms); Zhongguo hangye yibai qiang, 1995 (China's Top 100 firms by sector)

2.2 - The protected firms: the major State sector groups controlled by the centre in noncompetitive sectors 
In 1997, there were 2,097 large State-owned enterprises directly run by the central government. A little over one third were in deficit, and another third were in a precarious balanced financial situation. Although they represent only $0.4 \%$ of the total number of industrial firms, they still account for nearly $16 \%$ of total industrial production and $19 \%$ of the entire capital of industrial firms. These firms remain in their large majority off-limits for foreign investors, with only $2 \%$ of their capital being controlled by foreign companies. An examination of the classification of the country's 100 largest firms in 1997 shows that a great majority of these 2,097 firms operate in areas that are still strongly regulated and largely protected from both internal and international competition. Concerning the development of property rights, the State has on several occasions announced that it would preserve a majority of the capital in the big Stateowned enterprises. In the text adopted at the 3rd plenary session of the XVth Congress of the CCP in September 1999, the government declared that it wished to get out of non-strategic activities, yet without clearly defining this category. Although they have an urgent need of restructuring, the groups belonging to this category should not feel the influence of property reforms, except perhaps through a simplification of relations with the central ministries that oversee them. These have been grouped together since 1998, and the former bureaux for managing enterprises within the ministries have been reorganised into financial holding companies (guoyou zichan konggu gongsi), as shown in appendix $\mathrm{n}^{\circ} 1$. Similarly, for the largest firms in this category, the State Council has, since 1994, approved the creation of 156 groups which have received the right to manage State assets directly (shouquan) and to report directly to the central overseeing ministries without going through a financial holding company. There is therefore little to expect from this type of reform, in so far as even if the enterprises set up new 
institutions with a view to improving corporate governance, such as a board of directors or a monitoring council, the power structure remains totally dominated by the central ministries, either directly (in the case of 156 groups) or indirectly via the financial holding companies that continue to act like the former ministerial bureaux (see inset in appendix $\mathrm{n}^{\circ} 1$ ).

Furthermore, as clearly shown by E. Steinfeld in his study of the State-owned enterprises in the steel industry, the behaviour of the managers of these firms follows in the tradition of the major socialist firms (E.S. Steinfeld, 1998). Managers are still juggling with contradictory objectives, some of which are political, such as the respect of the CCP's goals. Despite closer attention being paid to financial profitability, these have frequently spilled over in recent times into questions associated with economic nationalism, such as the defence of national industry, and the advancement of the cause of "national technological champions" at the expense of technological and economic efficiency. Other objectives are more social in nature, like the growth in the work unit and the preservation for wage-earners of the advantages inherited from the socialist period. Finally, their career is first and foremost political, since being part of a company's management is often a springboard for moving up the hierarchy of the CCP and the State. These contradictory objectives encourage waste and other misuses of funds or deplete the State's resources, either to the benefit of wage-earners, whose increases in income (salaries and other social benefits directly underwritten by the company) remained until quite recently clearly above productivity increases.

From the point of view of financing, these enterprises are plainly the greatest beneficiaries of the official financial system. Although being far from the Korean situation, where the chaebols have long monopolised all sources of financing, the 1,000 biggest Chinese State-owned 
enterprises hold $63 \%$ of the industrial assets and still provide the central State with $70 \%$ of its fiscal revenue. The large State-owned enterprises have had access to all sources of official financing, whose development has been approved by the authorities. They have benefited from their political connections to gain privileged access to the major State commercial banks and to secure all existing forms of credit (K.J. 0'Brien, 1992) (subsidised loans, short-term credits, access to foreign currency for imports of technology). Apart from the early 1990s, they have been overwhelmingly directed at the stock market. Today, they constitute almost the entire number of the 1,000 enterprises listed on the two domestic stock markets, in Shanghai and Shenzhen, as well as those listed in Hong Kong (type "H" shares) or New York (type "N" shares). The interviews that we conducted, as well as other studies carried out in this area (E. Freund, 1997, X. $\mathrm{Xu}$ and Y. Wang, 1997), indicate that the impact of the financial market on their corporate governance has been limited. The State has locked in the capital of these firms in which it maintains an average participation close to $60 \%$, thereby discouraging private or foreign shareholders from taking over. Figure $\mathrm{n}^{\circ} 2-2$ shows that, since 1992, no appreciable drop has occurred in State control in the structure of capital. When it is realised that a non negligeable part of A and B type shares are also held by public institutions (State-owned enterprises, banks, firms controlled by local administrations), it becomes all the more clear to what extent the capital of companies listed on the Stock Exchange is still very largely controlled by the State. Private investors have put up money for purely speculative reasons, taking little interest in the management of the company. A recent three-year-long study of the Shanghai Stock Exchange and firms listed on it denounced in unambiguous terms the various types of interference practised by the relevant overseeing administrative bodies. Moreover, the domestic stock markets are forever 
being rocked by scandals associated with the spread of confidential information prior to IPO, and with the lack of transparency in the account-keeping practices of companies. The same study concluded saying that there is no direct relation ship between the evolution of share prices and the efficiency of the companies listed on the stock exchange. Finally, the way in which the laws are applied does not allow minority shareholders (even if they were to obtain strategic information about the company) to defend their rights before the courts. In this context, the control mechanisms derived from the financial market are severally limited.

These major State-owned enterprises have also benefited from the central government's policy of industrial group creation, that has authorised them to set up financial companies (subsidiaries) (caiwu gongsi) enabling them to raise funds for the group and manage its internal flow of financial resources. At the present time, 65 out of the list of 156 groups authorised by the State Council have been given the go-ahead to set up financial subsidiaries of this kind. In 1996, all such financial firms taken together had at their disposal 11 billion yuans in actual capital, 117 billion in assets, and took out loans totalling 63.5 billion yuans (54\% of assets), with 48.5 billion in short-term loans (76.4\%), and 15 billion in long-term loans (23.6\%).

In other terms, this type of enterprise should continue to siphon off a significant portion of bank credits, particularly due to the important needs of technological modernisation - nearly 280 billion yuans have been set aside for technological modernisation in the 9th Plan (1996-2000) and for their excessive payroll (the Angang steelworks still count nearly 300,000 employees).

Such firms have also been the sole beneficiaries of the recapitalisation programme of the State banks. This programme allows the debts of the State-owned enterprises to be converted into assets for the State banks. The bank wipes from its balance sheet the amount of the non profitable 
loan and the corresponding asset of the State-owned enterprise is taken over by liquidating companies created for the purpose (based on the American model of the late 1980s at the time of the savings cooperative banks crisis), which become responsible for selling it off. The difference between the initial value of the debt and the amount recovered through the asset sale should be financed by State bonds. For example, the Shougang steelworks in the capital signed an agreement in April 2000 with 3 of the 4 liquidating companies recovering unproductive assets Cinda, Huarong, and Dongfang -, enabling it to get rid of 3.5 billion yuans ( $\$ 430$ million) worth of debts (or non-profitable assets). The programme foresees over time (by the end of 2000) the cancellation of nearly 1,500 billion yuans in debts deriving solely from this category of the major groups in the State sector. In the month of September 2000, the 4 companies liquidating companies, are thought to have already bought back nearly 1,300 billion yuan worth of debts (\$157 million). However, from the point of view of an improvement in the system of corporate governance, the programme does not go to the root of the problem. The governor of the central bank declared in his annual speech in January 2000 that the cancellation of debts anticipated by this programme would constitute the last "free meal" to which the major State-owned enterprises would be entitled.

But these new liquidating companies, like the banks which are entering into the board rooms of these major State-owned enterprises, are unable to play their role as "active" stakeholder, namely to control the actions of managers and even less to censure them, and that for a variety of reasons: an asymmetry in information on the firm, that is knowingly controlled by the managers of State-owned companies, their lack of human resources and skills in terms of corporate governance, the high number of companies affected by the programme (nearly 1000) 
which multiplies the problems of competence, and finally, the statutes given to such companies, which do not bestow them with any absolute and real shareholder power, but rather a power that is subject to negotiation with the bureaucracies of the central ministries in charge of big state firms.

Concerning financing, the establishment of formal corporate governance institution within the firm should not eradicate the culture of free and plentiful financing, in which such companies have lived since their creation, something also pointed out by the OECD in its last report on the reform of Chinese firms (OECD, 2000). Only a hardening of the budgetary constraint due to external factors (bankruptcy, reformed banking system, opening up to foreign capital, competition) will bring about a greater financial rigour in these groups. 
Figure $n^{\circ} 2-2$ The evolution of the structure of the capital of Chinese firms listed on the stock exchange

Source : China's Statistical Yearbook of Stock Markets, 2000 (2000 nian, Zhongguo zhengquan qihuo tongji nianjian), p. 189

Finally, the last factor, one that is more difficult to appraise, and which works against any major changes to the system of corporate governance in this category of groups, lies in the fact that they constitute an important link in the chain of financing and patronage by the CCP. In spite of the greater importance having been given to economic efficiency by the CCP over the past 20 years, such firms remain subject to the objectives and strategies of the political leadership that very markedly go beyond those of a company in a developed economy, as A. Hussain and J. Chen recall in their study of Chinese groups (A. Hussain and J. Chen, 1999). According to one of the few studies published in China, carried out by the Shanghai Stock Exchange and devoted to the decision-making processes of firms listed there, $99 \%$ of the important investment decisions or those relating to the appointments of the top executive staff and their salary packages are taken by the firm's CCP committee in conjunction with the CCP's local authorities. Furthermore, even if very few analyses have been published on the subject in China, given the secrecy surrounding this phenomenon, the experiences of single-party political regimes elsewhere are sufficiently well-documented (see, for instance, J.R. Blasi, et al., 1997, S. Haggard and R.R. Kaufman, 1995, S. Maxfield and B.R. Schneider, 1997), for us to think that such a problem is very widespread in companies of this kind. In this context, the development of specific and intentional mechanisms for corporate governance such as board of directors, supervisory board have little chance of really 
being effective for this category of company. There is certainly more to be expected from the competition policy (particularly the opening up of the internal market to imports and foreign firms operating on Chinese soil), as well as from a vast reform of the banking sector, in order to improve their control and performance. From this point of view, China's entry into the WTO could, in some still-protected sectors, such as the automobile and steel industries, machine tools, or even telecommunications, impose a greater discipline on such firms, and speed up regroupings to reach a critical mass in order to face the competition battle coming from foreign multinationals for whom China represents a major market to be conquered (H.Wang, W. Wang and X. Richet (2000). However, in the agreement signed by China with the United States and the European Union, there remain a lot of restrictions to the opening up of the sectors that are today protected (such as telecommunications or the automobile industry, where foreign capital has a ceiling of $49 \%$ ) as well as grey areas which enable such firms to continue to enjoy protection in the national market. In parallel, the agreement on the WTO has given renewed impetus to the debate on economic nationalism. In spite of high levels of indebtedness, these groups are regarded by the Chinese government as the flagship of Chinese industry. That should enable them to continue to have access to virtually free finance in the name of the defence of national industry, thus perpetuating the lack of control over the use of investment resources. China's entry into the WTO could therefore have contradictory consequences for this category of firm.

Also, to the extent that the State remains the principal stake holder, the more it will be able to put in place and have respected a system of objectives (exports, profitability, technological innovation) and sanctions (an end to financing and assistance packages, disciplinary action for managers, privatisations, bankruptcies) that are clearly defined with respect to this type of group, 
the better corporate governance will be, as is shown by the experience in Korea (A. Amsden, 1989, K.J. Fields, 1995, R. Wade, 1990) and in other developing countries (P. Evans, 1995, S. Maxfield and B.R. Schneider, 1997).

\section{3 - The Winners: The Groups in the State and Collective Sector that are Leaders in the}

\section{Competitive Sectors.}

In areas such as retail electronics, household appliances, some parts of the food industry, textiles and clothing, which have been marked by price liberalisation, a lowering of the entry barriers for producers, and the development of unbridled competition, the past ten years have witnessed the advent of a new type of corporate groups (including in the collective sector) in which the State has a majority stakehold. Such firms, leaders in their respective market, like Haier, Huabao, Kelong (household appliances) Konka, TCL and Changhong (television sets), Legend (computers), have forged their reputations based on strategies which are in no way different from the major companies in capitalist economies. It is interesting to observe that such firms were far from figuring among the most well known ones in China at the end of the 1980s. Groups like Changcheng (Great Wall) in the computer industry, Mudan in Peking, or Panda in the province of Jiangsu, or again Shanghai Number One Television company, were all much more important firms receiving massive support from their parent authorities during the 1980s. The case studies that we have carried out on such leading conglomerates like Changhong (J.F. Huchet and X. Richet, 2000) and Konka, or the one produced by S. Kennedy on Stone (S. Kennedy, 1997) in the computer industry, show that whilst these firms have not been deliberately discriminated against in the industrial policy of the central or local State, they are far from having 
been supported, either financially or logistically, to any equivalent degree to that of the major State-owned enterprises which dominated their sector during the 1980s. The fate of a firm like Huaiyou in the province of Hebei in the city of Shijiazhuang is an interesting one in this respect. Considered as one of the largest conglomerates in the television manufacturing industry, the State gave it very broad access to bank finance in the 1980s, to import production lines from abroad, and to develop its distribution network nationally, well before all other domestic firms in the sector. However, right from the start of the 1990s, after serious errors of strategy in terms of diversification, difficulties in controlling its costs and a faulty assimilation of foreign technologies, the Huaiyou group quickly lost its position in the face of competition from more dynamic firms like Changhong. Huaiyou had to file for bankruptcy in 1993. As for Changhong, not having privileged access to the major sources of State finance, it used as best it could the human and technological skills left over from the Maoist period when it used to make military hardware, in order to assimilate foreign technologies. It was to aim small at the start, by favouring the province of Sichuan with its some (nonetheless) 100 million inhabitants, seeking to develop a distribution and after-sales service network that would make its reputation, at the same time as taking advantage of the low labour costs in the small city where it is set up (Mianyang), compared to those of its competitors (domestic and foreign) operating in the coastal provinces. Changhong launched a price war from the start of the 1990s, enabling it to benefit from economies of scale and to break into the national market as a whole, at the same time as maintaining a quality expectation for its products, making it very quickly the leading producer of television sets in the domestic market.

These firms also rather easily won their management autonomy, in so far as the State did 
not regard them as priority companies, which allowed them to reduce quite considerably the deleterious influence of bureaucratic interference in their decision-making. Most of these cutting edge firms are situated in medium-sized townships and not in large industrial cities. Due to their success, they have become important enough for the parent municipalities to have henceforth little leverage on them. Changhong has an annual turnover of more than \$US 2 billion dollars (Y. Chen, et al., 1999), mainly from its Mianyang factories, that is more than the city's income from taxation, or than the total combined turnover of the other companies operating in Mianyang municipality. The management of these companies has also gained a relative independence from their parent authority. The very strong personalities of their executive heads and the results achieved have led to a de facto privatisation of the management of these companies. The case studies that we have carried out show that the executives now have a free hand in virtually all the company's management decisions, with the exception of the sale or purchase of assets with respect to which the administrative authorities maintain a certain degree of control (J.-F. Huchet, 1999).

Their independence is also derived from their finance strategy. Not having benefited from the State's largesse in the 1980s, the first bank finances were put to good use, and the ensuing profits were reinvested in relatively well-planned new investments, thereby avoiding an overdependence on the State's banking sector. All these firms have in common the fact that they have a relatively low level of debt, not exceeding $50 \%$ in the majority of cases (when debts are taken as a ratio of the firm's capital). The development of the Shanghai and Shenzhen stock exchanges, or the possibility of being listed on the Hong Kong Stock Market, have been widely used by such firms which have been able to achieve a quick listing, in view of their reputation and 
performance. Given the still inadequate operation of the domestic stock exchanges (see above for category $\mathrm{n}^{\circ}$ ), which remain still largely incapable of influencing corporate governance, and even less of censuring the CEOs, managers of these companies saw the possibility of raising funds without any excessive countermeasure on the degree of control over their decisions, and of avoiding at the same time having recourse to bank credit that is synonymous with State control. Over time, this phenomenon could turn out to be prejudicial for such firms which, too sure of themselves, could launch into badly planned investments, without receiving any signs from the stock exchange likely to reorient their decisions. Nevertheless, the fact remains that at the present level of development of the Chinese economy, and paradoxically, this inadequate operation of the stock markets has allowed the leaders of such firms to not see their decisions as being dictated by the short-term profitability demands of financial investors.

Overall, the strong competition in their market combined with a privatisation of their management have considerably improved the system of corporate governance of such firms, even if institutions like the boards of directors and supervisory board that exist in these firms are far from operating in an efficient manner.

China's entry into the WTO should have an overall positive effect on their system of corporate governance. Competitive pressures should increase, yet without being a shock like that of the liberalisation policies put in place in the former socialist countries of Eastern Europe in the early 1990s. Indeed, these firms are already familiar with strong competition in their domestic market and have already incorporated a strong capacity for adaptation and reaction to the market into their management - a drop in excise, particularly in the areas of consumer goods, the food industry and textiles, in which China has a comparative advantage, should not entail overly 
severe shocks for these companies. Furthermore, they have massively invested over the past ten years in after-sales service networks focused on quality, which gives them a certain edge over foreign producers possibly tempted to invest heavily in China (some like Wirepool and Siemens having suffered some setbacks confronted with Chinese firms in the early 1990s, in their attempted penetration of the Chinese market). However, in the short to medium term, such leading firms are going to have to increase their portion of external finances, to allow a diversification and an increase in the quality of their products through $\mathrm{R} \& \mathrm{D}$, but also because they will have to consolidate their position in their main market by developing a vast distribution network and by buying up firms in other provinces.

From this viewpoint, both stock markets and domestic and foreign banks should constitute more important sources of finance and contribute to diversifying the control structures that for the time being rest solely on the competitiveness and personality of the present bosses. Since they have become market leaders, the State is more inclined to help them, particularly via the banking sector. The State has just granted 19 firms in this category \$US2.7 million each in subsidies that may be extended over 7 years so as to help them with their R\&D. Regarded as model enterprises, they will, however, need to skilfully steer clear of the pitfalls of the debate on the defence of national industry and the promotion of national champions by resisting the temptation of easy money handed out by the State, whence the soul-searching about the depolitisisation and professionalisation of the domestic banking sector. The faster these come about, the less chance there is that such companies will see a deterioration in their system of corporate governance.

Beyond the often strong and upright personality of their current bosses, they will also have to institute effective instruments of corporate governance (outside experts on their board of 
directors, recourse to the expertise of foreign investors). Beyond the nationalist rhetoric of the central government, one can be reasonably confident in these firms which have already a considerable experience in cooperating with foreign companies behind them (notably in terms of technology transfer and management methods), and in their ability to combine an intelligent strategy of cooperation/conflict with foreign companies in China as abroad. Such cooperation, indeed even the opening up of capital to foreign companies, should equally lead to a better functioning of the formal institutions of corporate governance in these firms, thus broadening the internal control mechanisms which are largely lacking today.

Overall, China's entry into the WTO should be beneficial for the system of corporate governance of these category of corporate groups by significantly increasing the opportunities for cooperation with foreign groups both in the industrial and financial fields, at the same time as strengthening competition in the domestic market.

\section{4 - "Sink or Swim": Small Groups in the State and Collective Sector}

These firms correspond to the bulk of State and collective small and medium-sized enterprises. In industry and for the State sector alone, they represented nearly $3 / 4$ of the some 110,000 State-owned enterprises in 1996. For the most part, such firms are experiencing significant financial difficulties (OECD, 2000). The figures vary according to the province. In the hinterland or in the north-east, where the State sector has the lion's share of the local economy, it is estimated that nearly $3 / 4$ of the State-owned small-and-medium-sized enterprises have either a deficit or precariously balanced books (Y. Lei, et al., 1999, Q. Xu, 1999). Conversely, in the coastal provinces, the situation is less of a concern with, depending on the estimate, between $30 \%$ 
and $40 \%$ of companies in the red or with a precarious balance sheet. Their influence is also less important in the local economy, where foreign investment and private enterprises represent an increasing part of activities (R. Benewick and S. Donald, 1999, J.-J. Boillot and N. Michelon, 2000).

This category of enterprise suffers from a system of corporate governance that is especially inefficient. Here are to be found, with only slight variations, the same problems as for the major groups in the State sector in category $\mathrm{n}^{\circ} 2$. There is, however, one (significant) difference, which is the inability of the local parent authorities to keep the manna of bank credit wide open to finance their existence, as they do for the large State-owned enterprises. The poor functioning of the internal control mechanisms (massive interference of the local bureaucracy in decision-making processes, inefficient management, the absence of any board of directors or supervisory board) has come on top of an inefficiency in the external control mechanisms (local anti-competitive protectionism, huge subsidies dressed up as bank credits, an absence of bankruptcies until recent years). It is not surprising therefore that the firms in this category which have not managed to respond to the challenge of competition under the guidance of a capable and honest CEO (in fact, the few ones which have succeeded that have moved into category ${ }^{\circ} 3$ ), woke up in the mid-1990s to a difficult financial situation. The rise of competition in the wake of an over-production capacity throughout Chinese industry, and the willingness to reduce subsidies disguised as bank credits in order to reform the State banks, sounded the death knell for such enterprises. It was in this context that the central State introduced in the mid-1990s a policy of drastic reform, summarised by the slogan "sink or swim", targeting such firms.

In parallel to the mergers and the leasing of management to a private individual, 
privatisation constituted the major axis of the restructuring of these enterprises. Whether it be complete privatisation with the sale of capital to outside investors, partial privatisation with the sale of a part of the capital to third-party companies, or privatisation with sale of capital to employees under the guise of cooperative stockholding (gufenhezuozhi), all these models have been tried to varying degrees by local governments. The economist Wu Jinglian recently estimated that nearly half the State-owned small-and-medium-sized companies may have been affected by one form or another of privatisation, which corresponds roughly to the drop in the number of State-owned enterprises, as reported in China's Statistical Yearbook 2000, which went from 120,000 in 1996 to 61,000 in 1999.

We are thus headed towards a stake-holding system of varying configurations among local players: the directors and employees of companies, the local governments represented by local State asset management companies (guoyou zichan guanli gongsi, see model $\mathrm{n}^{\circ} 1$ and insert $\mathrm{n}^{\circ} 1$ ), and, finally, either other State-owned enterprises, collective or private, or institutions linked to the local bureaucracy. In a general way, the local bureaucrats have not wished to see the most profitable firms get away from them. Personal rewards, CCP local financing, the continuation of a system of local patronage, all these factors explain to varying degrees this willingness to keep control over the most profitable enterprises. As we were able to note in our enquiries, confirmed moreover by other fieldwork studies (S. Sargeson and J. Zhang, 1999), the local political leaders control the whole privatisation process of asset evaluation, including allocation procedures all the way through to price fixing of the assets. We also accordingly find all the possible situations, from total privatisation to the maintenance of majority control via the (local) State assets management companies (see figure and insert in appendix $\mathrm{n}^{\circ} 1$ ). In the cases of total privatisation, 
particularly in medium-sized cities, the local leaders also often become the official new owners of the enterprises, through the use of figureheads, or by integrating the privatised enterprise into a group structure controlled by them (X.L. Ding, 2000). From this perspective, privatisation allows them to make all the subsidiaries that they have created or helped to create outside the State sector official, most often based on an abuse of State assets, and to set the whole up in a group structure of a financial holding type which has the (totally or partially) privatised State-owned enterprise at its core. When it is the company directors who assume control, they nonetheless need the cooperation of the local bureaucracies. The reform of ownership also allows the negotiation of a contract with the bureaucrats in exchange for a part of the privatised firm's capital (S. Sargeson and J. Zhang, 1999). The selling off cheaply of profitable State assets for the benefit of the local cadres or company directors was widespread enough to produce a critical backlash on the part of the central government at the end of 1998, putting a brake for a short while on such practices by local governments.

In the cases of partial privatisation, local governments have maintained majority control via the State asset management companies who act in fact like the former industrial bureaux of the municipalities (see insert $n^{\circ} 1$ ). Thus, despite the privatisation, we are far from observing any serious break with the mode of control of these enterprises, the bureaucracy remaining an inescapable player and one that often has a decision-making power for the most profitable companies.

The loss-making firms, on the other hand, have been either sold off to the employees or put on the market and sold off in asset exchange centres that have opened up shop in all of China's major cities (guoyou zichanjiaoyi zhongxin). With regard to the number of enterprises put 
on the market, very few foreign investors have risked taking up such firms, on account of the high transaction costs in this kind of operation and the rather unattractive nature of the assets of such firms (the level of indebtedness, obsolete technology, inefficient management, decreasing market share). We are not aware of any statistics published at the national level on the number of State-owned and collective small-and-medium-sized businesses taken up by foreign investors, but during our research in the provinces of Liaoning, Hubei, Shaanxi and Jilin, those in charge of the privatisation and sale of State assets confirmed to us that this concerned only one or two companies, sometimes not even any at all, as in Wuhan. The failure of the sale, for even one symbolic yuan, of State-owned enterprises in the city of Shenyang, during a European tour in 1998 of the political leaders from Liaoning province, bears witness to such difficulties. On the other hand, the cases of buy-back by Chinese investors have been much greater in number. There again, statistics are lacking. Nonetheless, during our case studies on the leading State-owned and private enterprises (categories 3 and 6), we have been able to observe that such firms had embarked on a path of external growth by buying up State-owned small businesses in other provinces. Since 1993, the private Chinese food industry group New Hope (whose head office is in Chengdu, in Sichuan province) had bought up 13 State-owned enterprises in various provinces. Between 1994 and 1998, the Haier group, $\mathrm{n}^{\circ} 1$ in household appliances in China, had already taken over around 15 State-owned enterprises in trouble in various provinces. The enterprises placed in the State assets exchange centres have not, however, all found buyers - far from it. The CEO of the Haier group, Zhang Huimin, has stated that the central administration, but also various local governments, regularly put pressure on the group for it to take over moribund enterprises in the sector. However, he added that he did not take on just any business in trouble, 
choosing rather those that had a good product, a market and good technology, but bad management. This meant that he was in a position of strength to negotiate take-overs in advantageous conditions, particularly in terms of debt reduction for the firm. The enterprises that have not been taken over by outside investors have either been merged with other enterprises in the region by administrative decision, sold off to employees, or, in a limited number of cases, have filed for bankruptcy.

The sale of the capital (in the form of shares) to the employees has in fact been the preferred method for reforming the urban State-owned and collective small-and-medium-sized enterprises in difficulty. Various provincial studies carried out in the inland provinces, in Ningxia (Q. Xu, 1999), Guizhou (R. Ma, 1999) and Sichuan (Y. Lei, et al., 1999), that we have crosschecked with our own interviews in Hubei, Shaanxi and Liaoning provinces, indicate that this method has been used in nearly $30 \%$ of the urban State-owned and collective small businesses affected by the reforms. The first large-scale experiment, and one that received a lot of media coverage, took place in Zhucheng in 1994, in a small city in Shandong province, where 210 State-owned and collective enterprises (out of a total of 288) were privatised (Y. Dong, 1999). This type of shareholding, called "cooperative", was extended to all of China's cities in the wake of the CCP's XVth Congress in the autumn of 1997.

What can be said about the influence of privatisation on the system of corporate governance of this category of firm? The most positive results have been recorded by enterprises bought up by outside investors (foreign or national). Such enterprises have not only been freed of bureaucratic shackles, but have also benefited from a new, more dynamic style of management, a brand name that is recognised by consumers and new outlets guaranteed by the new purchaser, as 
well as an easing of their debts with banks negotiated by the buyer with the local authorities. All these improvement have radically changed the system of corporate governance by strengthening the internal and external control mechanisms guaranteed by the buyer and no longer just by the local bureaucrats. In fact, such restructuring method, has amply proved its efficiency already in capitalist economies, as well as in former socialist countries of Eastern Europe, and broadly confirms the positions of certain economists, advocates of the agency theory, who think that the taking over of control by active investors in order to restructure an enterprise is clearly more efficient than the development of new internal control mechanisms within the firm (M.C. Jensen, 1997).

As far as firms whose capital has been sold off to its employees are concerned, the results seem rather negative. Once again, it is difficult to get a proper idea nationally, as no serious impact study has been published (or even perhaps carried out) by the central authorities. By comparing the enquiries we conducted in the inland and north-east provinces with provincial studies in the Chinese economic literature, two chief types of problem emerge, which have also been widely documented in other countries in transition, particularly in Russia (J. Blasi, 1997).

On the one hand, the capital injected from the sales of employee shares is too limited to eradicate the debts and provide a response to the needs of the restructuring that require a drastic modernisation of the whole production process. The enterprises in the city of Zhucheng, which were the first in 1994 on such a large scale to benefit from this type of privatisation, by 1997 had need of a new increase in capital to the tune of 750 million yuans (that is 3 times more than the first release of shares). The contribution of employees (which was the major part in 1994) amounted to only 180 million yuans (that is $24 \%$ of the total), the rest of the finance having been 
provided by the banks and outside investors who entered into the capital of the enterprises (Y. Dong, 1999). The intervention of the local State banks has been widely analysed as a bail-out package and a partial renationalisation of the city's firms. The banks also lent massively to company directors at the time of the initial purchases of shares as well as when they tried to buy back the shares of workers to secure a majority control of the firms (H. Zong, 2000). In short, after 3 years experience, the State has massively reentered into the capital of firms via the banks which, with limited capabilities and above all responding to the orders of the local authorities, risk having just as weak a grip over the firms as in the past.

On the other hand, the power structure and the incentive system that emerges from this type of privatisation are often incapable of generating any real reforming impulse within the enterprise. Admittedly, certain CEOs have an undeniable managerial know-how and may benefit from their new found autonomy with respect to the administration in order to put in train audacious reforms, as is shown by some of the success stories made much of in the Chinese economic press. However, the impact on control is generally limited, and for two main reasons. Firstly, the CEOs of the enterprises are still appointed by the local political leaders. They are still regarded as local functionaries. Their membership of the $\mathrm{CCP}$ also remains a determining factor for their career. This factor does not allow a break with the political allegiances that are sometimes contrary to the company's interests, but above all it encourages the pursuit of rent seeking strategies (which most often lead to corruption), the company CEOs considering themselves to be both poorly rewarded and not responsible for the firm's fate (even if they control a majority share of the capital which cannot be sold outside the company). Secondly, despite privatisation, there appears to be no countervailing power within the company, even when the 
employees have a majority holding in it. During the first few years following the initial sale of shares to employees, company directors sought to buy back the workers in order to become the majority shareholders. The workers unloaded their shares all the more quickly - in exchange for a few benefits - in so far as they sought to recover as fast as possible their savings that they had invested in the non negotiable shares outside the company. In larger cities, such as Wuhan or Chengdu, informal markets (guitai jiaoyi zhongxin) sprang up, enabling the workers to negotiate their shares with people outside the company. However, after repeated scandals in 1997 and 1998, these informal markets were banned by order of the central authorities. But it is especially the absence of free trade unions, the rise in unemployment and the end of jobs for life that have finally taken away from employees all organised and official means of pressure regarding their future and that of the company (T.W.Y. Leung, 1998, A. Walder, 1992). In this context, similar to what happened in Russia, none of the new institutions which have emerged from the privatisation process, such as boards of directors and supervisory board are in any position to exert any internal control over the actions or decisions of the companies' CEOs who, in most cases, assume the position of chairman of both the board of directors and the supervisory board, as well as being managing-director of the company and party secretary. These institutions still have little existence other than to rubber stamp decisions taken by the CEOs in consultation with the local bureaucrats. Finally, as regards the incentive system for workers, it was supposed to have been transformed by their new status as owners of the company. This influence, when it existed at all, operated only very briefly, just long enough for the workers to sell off their shares, and to realise that they had not won any real decision-making power or any real control in the company through privatisation. In fact, the above-mentioned factors, such as the threat of unemployment and the 
end of jobs-for-life, have proved to be much more powerful elements than the holding of shares in modifying the attitude of workers in their workplace (C.K. Lee, 1999, M. Zhao and T. Nichols, 1996).

Thus, this type of privatisation is far from constituting a sufficient condition for success in the restructuring process of this category of firm. In fact, improvement in the governance of such companies depends especially on an improvement in the external control system (the depoliticisation of banks so as to increase the budgetary constraint of firms, the deregulation or suppression of local protectionist measures so as to expose such firms to competition) and on the establishment of a system of social protection enabling preparation for the social costs associated with bankruptcies that should become more marked for this category of company. With an improvement in external control, the internal disciplinary mechanisms will have a greater chance also of improving, as in this category of firms the only companies that will survive will be those who succeed in reforming their management practices, and in limiting as far as possible the waste of resources stemming from the search for returns. There is nothing surprising in the fact that a greater proportion of these firms are experiencing better results in terms of restructuring in the coastal provinces, where local protectionism is not as strong as it was, where competition is stiffest, where the banks have better means of discriminating between firms in relation to their credit risk, and where the social security systems work well enough to enable the exit from the market of the most inefficient firms. (Z. Lu, 1999).

It is, however, for this category of firm that China's entry into the WTO should provide the rudest awakening. During the transitional phase in its entry into the WTO, we should see a pursuit of the reform of the banking sector in order to prepare the Chinese commercial banks for 
competition with foreign banks, as well as the lowering of tariffs and a greater opening up to direct foreign investment in hitherto protected areas. For these enterprises, this should result in a tighter budgetary constraint imposed by their principal creditor, namely the State banks, as well as by an upsurge in competition in the domestic market. The State-owned and collective urban small businesses, in spite of the wave of reforms, are the least prepared for taking on this twin challenge. Given their importance in terms of jobs in the inland and north-east provinces $(60 \%$ of the urban wage-earners live in these areas), we can expect the local leaders, with the assent of the central authorities, to put up non tariff barriers and ask the State banks to keep on subsidising the State-owned small businesses, and those recently privatised, so as to avoid the risks of social instability. Nevertheless, the choice of the Chinese authorities to join the WTO represents a clearly displayed willingness to put Chinese consumers first, who will be able to choose goods independently of the manufacturer's nationally (contrary to the development strategies being pursued by Japan, South Korea and Taiwan, who have given special treatment to national producers). We can therefore expect over the next few years a radical restructuring in which only a minority of these firms will continue to exist. The others will be either bought up (best case scenario), merged, or simply go into bankruptcy if China is capable of generating adequate growth and of redistributing it to those provinces most affected by the restructuring process. 
Table 2-2 : Diversity and Development in Corporate Governance of Chinese Groups

\begin{tabular}{|c|c|c|c|c|c|}
\hline & $\begin{array}{l}\text { Evolution of } \\
\text { property } \\
\text { rights }\end{array}$ & $\begin{array}{l}\text { Behaviour of } \\
\text { the Board of } \\
\text { Directors }\end{array}$ & $\begin{array}{l}\text { Behaviour of } \\
\text { managers }\end{array}$ & $\begin{array}{l}\text { Finance } \\
\text { strategy and } \\
\text { budgetary } \\
\text { constraint }\end{array}$ & $\begin{array}{l}\text { Role of the } \\
\text { Party }\end{array}$ \\
\hline $\begin{array}{l}\text { Major State } \\
\text { groups in } \\
\text { the non- } \\
\text { competitive } \\
\text { sectors }\end{array}$ & $\begin{array}{l}\text { Privatisation } \\
\text { very unlikely }\end{array}$ & $\begin{array}{l}\text { No decision- } \\
\text { making role } \\
\text { Strong } \\
\text { interventionis } \\
\text { t role of the } \\
\text { central } \\
\text { ministries via } \\
\text { financial } \\
\text { holding } \\
\text { companies. }\end{array}$ & Political & $\begin{array}{l}\text { Soft budget } \\
\text { constraint. } \\
\text { Continues to } \\
\text { benefit from } \\
\text { the } \\
\text { extravagance } \\
\text { of the } \\
\text { domestic } \\
\text { banking and } \\
\text { financial } \\
\text { system. }\end{array}$ & Very strong \\
\hline $\begin{array}{l}\text { The State- } \\
\text { owned and } \\
\text { collective } \\
\text { groups that } \\
\text { are leaders } \\
\text { in the } \\
\text { competitive } \\
\text { sectors }\end{array}$ & $\begin{array}{l}\text { The State } \\
\text { remains the } \\
\text { principal } \\
\text { stakeholder, } \\
\text { but there is } \\
\text { de facto } \\
\text { privatisation } \\
\text { in favour of } \\
\text { managers }\end{array}$ & $\begin{array}{l}\mathrm{W} \text { e a } \mathrm{k} \\
\mathrm{d} \text { e c i s i o } \mathrm{n}- \\
\text { making role } \\
\text { I } \mathrm{n} \mathrm{t} \text { e } \mathrm{r} \text { a } 1 \\
\mathrm{c} \text { o } \mathrm{n} \mathrm{r} \text { o } 1 \\
\text { through chief } \\
\text { executives } \\
\mathrm{L} \text { o c a } 1 \\
\text { governments } \\
\text { maintain an } \\
\text { influence in } \\
\mathrm{t} h \\
\text { management } \\
\text { of assets even } \\
\text { if the power } \\
\text { of managers } \\
\mathrm{t} \text { e } \mathrm{n} \mathrm{d} \mathrm{s} \text { o } \\
\text { increase. }\end{array}$ & $\begin{array}{l}\text { Increasingly } \\
\text { profit seeking } \\
\text { oriented }\end{array}$ & $\begin{array}{l}\text { Hard budget } \\
\text { constraint. } \\
\text { Based on } \\
\text { capacity for } \\
\text { self-financing } \\
\text { and the } \\
\text { stocket } \\
\text { market } \\
\text { Non official } \\
\text { finance? } \\
\text { Low debt } \\
\text { level }\end{array}$ & $\begin{array}{l}\text { R e m a i n } \\
\text { present but in } \\
\text { decline } \\
\text { P o s s i b } 1 \mathrm{e} \\
\text { conflicts over } \\
\text { time w ith } \\
\text { firm strategy }\end{array}$ \\
\hline
\end{tabular}




\begin{tabular}{|c|c|c|c|c|c|}
\hline $\begin{array}{l}\text { Small } \\
\text { groups in } \\
\text { the State } \\
\text { and } \\
\text { collective } \\
\text { sector }\end{array}$ & $\begin{array}{l}\text { Policy of } \\
\text { "sink or } \\
\text { swim" } \\
\text { Move } \\
\text { towards } \\
\text { privatisation }\end{array}$ & $\begin{array}{l}\mathrm{W} \text { e } \mathrm{a} \text { k } \\
\mathrm{d} \text { e c is i o } \mathrm{n}- \\
\text { making role } \\
\text { I } \mathrm{n} \mathrm{t} \text { e } \mathrm{n} \text { a } 1 \\
\mathrm{c} \text { o } \mathrm{n} \mathrm{t} \mathrm{r} \text { o } 1 \\
\text { through chief } \\
\text { executives or } \\
\text { local State } \\
\text { a s } \mathrm{s} \mathrm{e} \mathrm{s} \\
\text { management } \\
\text { companies. }\end{array}$ & $\begin{array}{l}\text { Trying to } \\
\text { survive }\end{array}$ & $\begin{array}{l}\text { soft budget } \\
\text { constraint } \\
\text { Heavily } \\
\text { indebted } \\
\text { System of } \\
\text { cross } \\
\text { participation } \\
\text { between local } \\
\text { firms }\end{array}$ & Decline \\
\hline $\begin{array}{l}\text { Private } \\
\text { groups in } \\
\text { the } \\
\text { competitive } \\
\text { sector }\end{array}$ & $\begin{array}{l}\text { Strengthenin } \\
\mathrm{g} \text { of the } \\
\text { protection of } \\
\text { private } \\
\text { property } \\
\text { rights }\end{array}$ & $\begin{array}{l}\text { Importance } \\
\text { of family } \\
\text { control }\end{array}$ & $\begin{array}{l}\text { Profit seeking } \\
\text { oriented }\end{array}$ & $\begin{array}{l}\text { Hard budget } \\
\text { constraint } \\
\text { Self- } \\
\text { financing and } \\
\text { unofficial } \\
\text { financing } \\
\text { Willingness } \\
\text { to self- } \\
\text { finance on } \\
\text { the stock } \\
\text { market and } \\
\text { through } \\
\text { foreign banks }\end{array}$ & $\begin{array}{l}\text { Limited, } \\
\text { but need to } \\
\text { be sure of the } \\
\text { CCP's } \\
\text { protection }\end{array}$ \\
\hline
\end{tabular}


Table 2-2 (continued) : Diversity and Development of the Corporate Governance of Chinese Groups

\begin{tabular}{|c|c|c|c|}
\hline & $\begin{array}{l}\text { Salary growth } \\
\text { Fringe Benefits } \\
\text { Bargaining power of } \\
\text { workers }\end{array}$ & $\begin{array}{l}\text { Expected results of } \\
\text { the reforms to the } \\
\text { system of corporate } \\
\text { governance }\end{array}$ & $\begin{array}{l}\text { Impact of entry into } \\
\text { the WTO }\end{array}$ \\
\hline $\begin{array}{l}\text { Major State groups } \\
\text { in the non- } \\
\text { competitive sector }\end{array}$ & $\begin{array}{l}\text { Stable bargaining } \\
\text { power } \\
\text { Continues to benefit } \\
\text { from fringe benefits } \\
\text { Rise in salaries likely } \\
\text { to continue to be } \\
\text { above growth in } \\
\text { productivity }\end{array}$ & $\begin{array}{l}\text { Weak influence } \\
\text { Remain under the } \\
\text { inefficient control of } \\
\text { the central } \\
\text { bureaucracy }\end{array}$ & $\begin{array}{l}\text { Little impact, are } \\
\text { going to seek } \\
\text { government support } \\
\text { to protect themselves } \\
\text { against competition } \\
\text { and to continue to } \\
\text { have access to } \\
\text { finance from State } \\
\text { banks }\end{array}$ \\
\hline $\begin{array}{l}\text { State and collective } \\
\text { groups, leaders in } \\
\text { the competitive } \\
\text { sector }\end{array}$ & $\begin{array}{l}\text { Negotiating power } \\
\text { declining with the } \\
\text { increase of } \\
\text { unemployment } \\
\text { Growth rate of } \\
\text { salaries below that of } \\
\text { productivity, but } \\
\text { possibility for } \\
\text { compensation } \\
\text { through share } \\
\text { allocations } \\
\text { New management } \\
\text { interested in } \\
\text { developing the pool } \\
\text { of technological skills }\end{array}$ & $\begin{array}{l}\text { Could take advantage } \\
\text { of the reforms. More } \\
\text { autonomy, better } \\
\text { access to different } \\
\text { forms of finance, in } \\
\text { particular on the } \\
\text { stock and bank } \\
\text { markets. } \\
\text { Stronger pressure of } \\
\text { financial markets if } \\
\text { the banking reform is } \\
\text { implemented. } \\
\text { Withdrawal of the } \\
\text { Party/State from } \\
\text { restructuring and } \\
\text { group creation } \\
\text { activities. }\end{array}$ & $\begin{array}{l}\text { Potential winners } \\
\text { Second phase in their } \\
\text { development: } \\
\text { difficult strategic } \\
\text { decisions, have to } \\
\text { position themselves } \\
\text { with higher value } \\
\text { added goods. } \\
\text { Possible reform of } \\
\text { management through } \\
\text { cooperation with } \\
\text { foreign companies } \\
\text { entering the firm's } \\
\text { decision-making } \\
\text { bodies. } \\
\text { Will have to avoid } \\
\text { the risks linked with } \\
\text { the policy of } \\
\text { defending national } \\
\text { industry }\end{array}$ \\
\hline $\begin{array}{l}\text { Small groups in the } \\
\text { State and collective } \\
\text { sector }\end{array}$ & $\begin{array}{l}\text { Negotiating power on } \\
\text { the wane with the } \\
\text { growth of } \\
\text { unemployment }\end{array}$ & $\begin{array}{l}\text { Weak influence } \\
\text { Risk of insiders } \\
\text { control as in Russia }\end{array}$ & $\begin{array}{l}\text { The big losers. } \\
\text { High transactions } \\
\text { costs for foreign } \\
\text { investors } \\
\text { Bankruptcies and } \\
\text { mergers, and } \\
\text { privatisation }\end{array}$ \\
\hline
\end{tabular}




\begin{tabular}{|l|l|l|l|}
\hline $\begin{array}{l}\text { Private groups in } \\
\text { the competitive } \\
\text { sector }\end{array}$ & $\begin{array}{l}\text { Negotiating power } \\
\text { declining on account } \\
\text { of the increase in } \\
\text { unemployment } \\
\text { Growth rate of } \\
\text { salaries below that of } \\
\text { productivity, but } \\
\text { possibility for } \\
\text { compensation } \\
\text { through share }\end{array}$ & $\begin{array}{l}\text { Could take advantage } \\
\text { of the reforms. More } \\
\text { autonomy, better } \\
\text { access to different } \\
\text { forms of finance, in } \\
\text { particular on the } \\
\text { stock markets and } \\
\text { through foreign } \\
\text { banks. }\end{array}$ & $\begin{array}{l}\text { Potential winners. } \\
\text { May win if the Party/ } \\
\text { State keeps its } \\
\text { promises to grant the } \\
\text { private sector greater } \\
\text { access to finance and } \\
\text { gives them greater } \\
\text { intepresentation } \\
\text { interested in } \\
\text { reveloping a pool of } \\
\text { nationally with less } \\
\text { interference at the } \\
\text { micro level }\end{array}$ \\
& technological skills & & \\
\hline
\end{tabular}




\section{5 - Tomorrow's Winners? Private Groups in the Competitive Sectors}

Finally, the last category brings together the private enterprises that have succeeded in reaching a critical mass in competitive sectors of the market. Private firms have experienced rapid development since the end of the 1980s. Statistics vary depending on the source, the directory of private companies putting forward the figure of $1,280,000$ officially registered firms, while a recent governmental study indicated for 1999 that it was rather around the 960,000 mark, with 13.5 million employees. In the vast majority of cases, however, the private companies are small in size and mainly operate around the family unit in the service sector, particularly in the restaurant business, or small commercial activities in urban areas (category $\mathrm{n}^{\circ} 7$ ). But a study of their situation goes beyond the object of the present article.

There also exists a particular category of private firms whose number is hard to estimate and about which we have not obtained enough information. These are private companies (or registered as such) set up and managed via figureheads by local bureaucrats or directors of Stateowned enterprises. It is difficult to evaluate their performance, in so far as such companies survive under the umbrella of local protectionism and by siphoning off assets from State-owned enterprises (X.L. Ding, 2000).

The companies that are of interest to us here are only a handful, and are precisely those that have managed to get beyond the frame of the small family business. The country's first private enterprise, New Hope (Xinxiwang), whose headquarters are in Sichuan province, is a leader in the animal food industry, with a turnover of nearly 2 billion yuans (\$US 240 million) in 1998. Only 3 private companies (New Hope, Sichuan Tongwei, and Beijing Changning), had a turnover greater than a billion yuans. By way of comparison, the 1997 turnover of the top 5 
Chinese groups (all State-owned enterprises) was 35 times greater than that of the 5 biggest private enterprises (R. Tung, 1997).

Their control structure has remained relatively simple since these companies have been set up by an individual, sometimes a family, who directly runs the operation. Their performance is all the more remarkable in relation to the leading State-owned enterprises in category $\mathrm{n}^{\circ} 3$, in so far as they have been very largely discriminated against in terms of access to finance and raw materials. This discrimination has been especially acute in the hinterland and north-east regions, where the State-owned enterprises remain dominant in the local economy and the bureaucracy carries on a predatory stance with regard to private capital. In Wuhan, short-term loans granted to private enterprises in 1996 represented only $1 \%$ of the total amount of short-term loans provided by the banking sector. Even in Guangdong province where private enterprises are highest in number, the credits granted by the 4 major State commercial banks (which still monopolise the field of credit extended to companies), did not exceed $1 \%$ of the overall amount of credit handed out to companies. Despite central government directives, the banks remain very cautious with loans, considering in particular that private enterprises are unable to provide good quality collateral when they take out credit. It is therefore not surprising that institutions like IFC (International Finance Corporation, a subsidiary of the World Bank specialising in loans to the private sector in developing countries) have until recently had great difficulty in China in financing projects that are solely in the private sector. In its 12 years in the Chinese market, IFC had (by late 1997) financed only 40 projects for a total of \$US1.5 billion, and only two projects had been concluded with fully private enterprises - the other projects concerned Sino-foreign firms. The only sources of finance available for private firms have been of the self-funding type, 
informal channels of finance - for the most part regarded as illicit - and similarly, albeit more tangentially, rural and urban credit cooperatives. It is difficult to find figures nationally concerning the importance of such recourse to informal channels of financing, but one study dealing with rural collective enterprises indicates that what is grouped together under the Chinese name of minjian jiedai shichang (popular credit market, including tontines, loans from private individuals, as well as assistance and loans from the family) might account for between a quarter and a third of the total amount of their finances (D. Zhu and H. Hu, 1997). The small-to-mediumsized businesses in Taiwan and Korea were, until the 1980s, facing a similar situation with financial markets that remained under tight political control and were mainly intended to service the major firms close to the Nationalist Party in power in Taiwan, or the chaebols in South Korean (K.J. Fields, 1995). Paradoxically, in the initial phase of the development of Chinese private firms, such rationing of finance constituted an effective external control, to the extent that those in charge were forced to avoid wasting resources and to reinvest a large part of their profits to ensure growth.

Such companies could in the near future be the big winners on the internal industrial scene. The political discrimination by the regime against the private sector is not anymore explicit as it use to be in the 80 's . The National People's Congress voted a constitutional amendment in 1999 recognising the place of the private sector alongside the State sector in the nation's economic development, and the the State Planning Commission has just announced that the Chinese government is going to lift all forms of restriction and discrimination against the private sector. A few private enterprises have won legal proceedings against local administrations, something that was unimaginable at the beginning of the 1990s. The private firm New Hope 
(Xinxiwang) became in 1998 the largest shareholder in the Minsheng Bank - the sole private commercial bank to exist in China -, with $9.9 \%$ of the bank's capital. Moreover, the bank has invited the principal managers of the major private enterprises onto its board of directors. By the same token, in January 1999, 41 private firms obtained permission to trade abroad, and more private firms should be authorised to join the Shanghai and Shenzhen stock exchanges. Discrimination regarding private firms should ease off as the regime knows that it has a problem, linked to population growth, that is difficult to solve without the help of the private sector. The Chinese economy created 287 million new jobs between 1978 and 1996, but this pace has considerably slowed since 1990. Between 1978 and 1990, 238 million new jobs were created, that is at an average rate of nearly 20 million new jobs per annum. Between 1990 and 1996, only 49 million new jobs were created, that is at an average annual rate of about 8 million (J.-F. Huchet, 1998). But several structural reasons indicate that the employment situation should not pick up in the coming years. Despite the fall in the birthrate since the late 1970s, on average 15 million people will arrive on the labour market every year 2010. Furthermore, the rural collective enterprises that absorbed a good part of the oversupply from the countryside during the 1980s, are now creating fewer and fewer jobs. From 1978 to 1988, employment in such firms grew on average at the rate of 7\% per annum, whereas it was only 5\% between 1988 and 1996. Productivity gains, concentration and other sectorial restructuring plans to deal with the present overcapacities in industry, mean that this category of firm will not be in a position to create as many jobs as in the 1980s. As to the State sector, it contributed to half of the jobs created between 1978 and 1995 in urban areas, but it has now entered a phase of job elimination that will be more or less accelerated depending on the political and financial demands. Despite rapid growth in job 
creation in Sino-foreign firms, with nearly 30 million employees (F. Lemoine, 2000), this category of firm will be unable to absorb alone all of the new job seekers coming onto the labour market, in addition to the unemployed.

Thus, the rise in unemployment and the development of a political ideology with regard to the private sector could result in a noticeable improvement in access to official financing and in the respect of property rights. The factors likely to promote the development of the private sector go well beyond the mere context of economic policy. The willingness of the present political rulers to accept the appearance of really independent private economic powers, along the lines of the nationalists' transition in Taiwan in the mid-1980s (yet so decried in China), will be decisive in enabling the emergence of major private groups. The amount of room for manoeuvre that such firms have vis a vis the local and central bureaucracies remains after all quite limited, with the administration having no qualms in closing down private firms that threaten local monopolies or throwing into prison bosses of private companies seeking a free rein from the CCP. Liu Yonghao, the managing director of New Hope, readily confesses in interviews to not being a member of the $\mathrm{CCP}$, but he is nonetheless fairly well coopted by the regime into taking his place on the National Consultative Conference of the Chinese People. Without fail, Chinese private businessmen bear witness to the need to have the CCP on side for their business dealings (J. Becker, 2000). Private businessmen are represented by two associations, one for individual workers (geti laodongzhe xiehui, concerning small private businesses) and the other for private firms (siying qiye xiehui), which only operate at a local level, under the watchful eye of the local organs of the CCP (O. Bruun, 1993). Both these associations are represented nationally by the very official Federation of Industry and Commerce which is, there again, very largely controlled by the CCP (G. White, et 
al., 1996).

China's entry into the WTO should be beneficial for the corporate governance of private groups, just as for the leading State-owned enterprises in category $n^{\circ} 3$. Such groups should, like foreign companies, benefit from progressive deregulation in certain still protected activities. Furthermore, the possibility for self-financing through foreign banks is eagerly awaited by such firms who are mistrustful of the State banks, which, in their eyes, are tantamount to State interference in their management. The directors of New Hope have clearly indicated to us that they were seeking to establish relations with foreign financial institutions. This would enable them to ease domestic political constraints in terms of finance, at the same time as strengthening the outside control of their investment decisions. The agreement on the WTO should, moreover, speed up the merger on the stock exchange between the market in "A" stocks (reserved for nationals only) and the one in "B" stocks (open to foreign investors), thereby opening up the possibility of a participation by foreign groups in the capital of the major private companies listed in Shanghai or Shenzhen, or even a taking over of control, which would tighten the disciplinary mechanisms derived from the financial markets.

\section{Conclusion}

This review of the state and possible developments in the corporate governance of various categories of Chinese groups allows us to measure to what extent the emergence of competitive forces in Chinese industry has constituted the most effective factor in controlling the actions of company executives. Given the poor effectiveness of the mechanisms outside the firm (application of laws, labour market, political system) which are supposed to support the 
functioning of traditional mechanisms (board of directors, supervisory board, remuneration of senior executives) that China is seeking to introduce, competition in the goods and services market should, for several years yet, remain the most effective mechanism for regulating the behaviour of executives. Against this background, China's entry into the WTO should allow an increase in competition in still protected areas, and thereby push businesses to restructure even more quickly.

Nevertheless, competition alone seems very far from being able to contribute to the emergence of systems of efficient corporate governance. Indeed, it acts a posteriori, once the investment decisions have been taken, the market then choosing the most effective units. It is not by chance that China has, since the mid-1990s, been paying the price for investments made in the 1980s and early 1990s, that were badly planned, under-sized and ill-adapted to the market. This price to pay is far from being negligible, if we think in terms of the recapitalisation needs of the banking system which, at the end of the cycle, reflects the quality of investment decisions. In a recent article, N. Lardy even raises the prospect of a rapid deterioration in the fiscal situation associated with the recapitalisation needs (N.R. Lardy, 2000). A more efficient approach to corporate governance would precisely enable company decision-makers, before taking their decisions, to get some indication of likely success of their investments. Overall, it would allow a better use to be made of national savings (whatever their importance, as in the case of China).

As to the administrative reforms of the State assets management system, we have seen that they are primarily about an internal reorganisation of the bureaucracy's prerogatives, without really changing in any way the efficiency of the mechanisms for controlling companies.

The Chinese government therefore needs to work on several fronts at once, not only to 
respond to the distinct needs arising from the various categories of company, but also to improve the functioning of other disciplinary mechanisms that will come to reinforce the effects of competition. This concerns the pursuit of reforms in the banking and financial sector - and doing so much more fundamentally than hitherto -, the fight against regional protectionist measures, an improvement in the labour market, particularly regarding company managers, and the further development of the rule of law and a freer press.

Such reforms go well beyond the mere economic sphere, making them at once more complex and difficult to implement, as they mean forcing change on institutions affecting economic or political interests but that are difficult to budge, all the more so in present political circumstances. This also explains why the economic reforms have now entered a different phase, and one that is more difficult than that of the 1980 s, during which time what mattered was to bring reform at the periphery of the economic system, without going to the very core of its organisation (property rights, system of financing, judicial environment, social protection and so on).

From this point of view, relating these reforms to the present macro-economic situation is of fundamental importance. In line with other countries in transition, this phase in the reform process is producing losers (the destruction of productive capacities, unemployment, a change in the bureaucracy, the privatisation of services provided by the former socialist system) and so behavioural changes that impact on the pace of economic growth (like the rise in savings that has been having a downward effect on consumption for nearly the past two years in China). Hence, China must expect to carry out deep and complex structural reforms in the context of slowed growth in comparison to the levels of the 1980 s and early 1990 s, with an increase in its working 
population as part of the equation, which does not make matters any easier. In this connection, the future will tell whether a political system, which is systematically holding back the emergence of counterbalancing powers in companies, as it is in civil society, thereby restricting the production of mechanisms for controlling those who wield power in the companies, will be in a position to respond to such challenges. 
Appendix $n^{\circ} 1$ Reform of the state asset management system

Organisation of the administrative system for management of State assets 


\section{Insert n'1}

\section{The development of State assets management companies}

In parallel to the corporatisation of State-owned enterprises, the central government has reformed the system of State assets management. In this, it had a number of objectives:

1 - To put a break on the misappropriation of State assets.

2 - To go with the reform of the administration by enabling the elimination of the bureaux responsible for managing State-owned enterprises in the ministries and local administrations.

3 - To break once and for all with the proliferation of the relevant administrative bodies in the area of corporate governance.

The figure sets out the main lines of the new organisation. At the level of the central administration, the State assets management Commission is supposed to manage all State assets on behalf of the Ministry of Finance, along the lines of the systems in Europe or Singapore. For the major State-owned enterprises (category $\mathrm{n}^{\circ} 2$ ), it delegates its executive powers, either to financial holding companies (konggu gongsi) normally specialising in one particular branch of activity, or directly to major groups that have a monopoly hold on the national market (for example CNPC and SINOPEC in the petrochemical industry). For smaller State-owned enterprises run by local governments (categories $n^{\circ} 3$ et $n^{\circ} 5$ ), it delegates its powers locally to State assets management commissions. Such commissions delegates day to day works to State 
assets management companies (guoyou zichan jingying gongsi), that play an executive role similar to the financial holding companies at the central government level. Such companies first of all have to secure the present value of the State assets. But they may equally decide to sell off a part or the whole of the assets that they hold in a particular company. In the case where the sale of shares leads to a change of majority ownership, they must seek authorisation from the State assets management commission (the central commission for large firms, a municipal one for smallersized State-owned enterprises run by local governments). They are also supposed to contribute to the restructuring of the firms. As shareholders, most often majority shareholders, they hold the power in the company boardrooms. The chairman of the board is a representative of these State assets management companies, in general its managing-director. They also appoint the company directors. At the local administrative level, Shanghai, Wuhan, and Shenzhen were the first to develop this type of company. Shanghai began the experiment in 1994 and now has around forty of them, each company managing State assets in a clearly defined industrial area (C. McNally, 1997). Since the XVth Congress of the CCP in the autumn of 1997, nearly all the major municipalities have set up this kind of company.

In reality, however, the reform process is far from having reached all its declared objectives:

- The Ministry of Finance, which wished to become the sole institution responsible for State assets through the State assets management commission, has still to share its power. Indeed, the financial holding companies or the major State groups remain largely controlled by the central ministries. The financial holding companies are in most cases outgrowths of the former ministerial bureaux, and the major groups still report directly to the central ministries. Moreover, 
at the local level, the various interviews we had in Wuhan, Chengdu and Shenyang, and which we have been able to confirm through other fieldwork studies carried out in Shanghai, Xiamen, Shenzhen and Nanning (Z. Lu, 1999, E. Cheng, 1999, X. Chenhong, 1999, Kejizu, 1999, R. Ma, 1999), show that the central State assets management commission has in fact very few powers over the local State assets management commissions, which are entirely controlled by the municipal governments. The latter appoint the members of the commission (the presidency of the commission often being taken on by the mayor or the CCP secretary of the city), as well as those of (local) State assets management companies. The municipalities have in fact been eager to create this type of company, thereby enabling them to specify the companies that de facto belong to them in their relevant geographical area, in order to protect their fiscal base. This is also confirmed by A. Hussain and C. Jian in their study of the reforms of Chinese companies (A. Hussain and J. Chen, 1999). In Wuhan, for example, the Wugang steelworks or the motorcar manufacturer Dongfeng do not figure among the local State assets as, in their capacity as largescale firms, they are run directly by Peking.

- The (local) State assets management companies are, just as happens centrally, outgrowths of the former industrial municipal bureaux responsible for the management of companies. Even if the employees of such companies have given up their status as functionaries, the staff comes in large part from the former local industrial bureaux or the economic commissions of the townships. Thus we find the same defects in the control structures as in the past, namely bureaucratic interference that coexists with a faulty control of the use of resources and the actions of those in charge (an asymmetry in terms of information, a lack of responsibility among the companies' leaders, phantom boards of directors and supervisory boards etc...). 
- The creation of State assets management companies or financial holding companies could have facilitated a decompartmentalisation of sectors by encouraging the movement of assets from one to another according to the particular industrial strategies followed by the firms. However, in the majority of cities visited, the municipalities had set up as many companies for managing State assets as there are major industrial sectors, thereby basically reproducing the compartmentalisation into sectors that prevailed in the former system. Only Shenzen had created no more than one company for managing State assets. However, this difference can be explained through its late industrialisation and the low number of State-owned enterprises under the wing of the municipal government. Even the city of Wuhan, which seemed to opt for a single State asset management company until 1998, thus setting itself up in opposition to the Shanghai experiment (which created nearly 40 companies of this sort), subsequently decided to open 3 new companies for managing State assets, taking over, as it were, the attributions of the former industrial bureaux.

- Finally, neither the financial holding companies nor the local State asset management companies have played a major role in the restructuring process. The lack of finance, administrative interference, local protectionist policies and actions, the lack of qualified staff, poorly defined regulations, have all led them to conduct a portofolio approach to asset management instead of behaving like real restructuring agencies in the mould of certain institutions set up in the countries of Eastern Europe in transition. 


\section{Bibliography}

Amsden A., Asia's Next Giant: South Korea and Late Industrialization, Oxford, Oxford University Press, 1989.

Andrieu Jacques, "Chine : une économie communautarisée, un Etat décomposé" ["China. A Community-based Economy and a Crumbling State"], in Revue Tiers Monde, t. XXXVII, $\mathrm{n}$ ${ }^{\circ} 147$, pp. 669-87.

Aoki Masahiko, "Controlling Insider Control: Issues of Corporate Governance in Transition Economies", in Aoki M. and Kim H.-K. (ed.), Corporate Governance in Transitional Economies, Washington D.C., World Bank, 1995, pp. 3-28.

Benewick Robert and Donald Stephanie, The State of China Atlas, London, Penguin, $1999,128 \mathrm{p}$.

Blasi Joseph, "Corporate Ownership and Corporate Governance in the Russian Federation", in Lieberman I. W., Nestor S. S. and Desai R. M. (ed.), Between State and Market. Mass Privatization in Transition Economies, Washington D. C., The World Bank \& OECD, 1997, pp. $162-70$.

Blasi Joseph R., Kroumova Maya and Kruse Douglas, Kremlin Capitalism. Privatizing the Russian Economy, Ithaca, Cornell University Press, 1997, 249 pp.

Becker Jasper, The Chinese, London, John Murray, 2000, 464 pp.

Blecher Marc and Shue Vivienne, Tethered Deer, Government \& Economy in a Chinese County, Standford, Standford University Press, 1996, 267 pp.

Berglöf Erik. and Romesh Vaitilingam, Stuck in Transit: Rethinking Russian Economic 
Reform, London, CEPR, 1999

Boillot Jean-Joseph and Michelon Nicolas, "La Nouvelle géographie économique du monde chinois" ["The New Economic Geography of the Chinese World"], in Perspectives Chinoises, ${ }^{\circ} 59$, pp. 14 - 37.

Boone P., Gomulka S. and Layard R. (ed.), Emerging from Communism. Lessons from Russia, China and Eastern Europe, Cambridge, The MIT Press, 1998,

Breslin Shaun, China in the 1980s. Centre-Province Relations in a Reforming Socialist State, London, Macmillan, 1996, 180 pp.

Broadman Harry, "China's Membership in the WTO and Enterprise Reform: The Challenge for Accession and Beyond", Discussion Paper, The World Bank, 2000, 21 pp.

Bruun Ole, Business and Bureaucracy in a Chinese City, Berkeley, Institute of East Asian Studies, 1993, 272 pp.

Cao Yanzheng, Qian Yingyi and Weingast Barry R., "The Sale Goes on. Transforming Small Enterprises in China", in Transition, February 1998, pp. 5 - 7.

Chan Vincent, "Job Creation or Capital Return", in Warburg Dillon Read, November 1998, pp. 10- 8 .

Charreaux Gérard (ed.), Le gouvernement des entreprises. Corporate Governance. Théorie et faits, [Corporate Governance in Theory and Practice] Paris, Economica, 1997, 540 pp.

Cheng Enfu, "Shanghai guoyou zichan yunxing fenxi" (an analysis of the operation of State assets in Shanghai), in Guoyou Zichan Guanli, n³, 1999, 1999, pp. 44 - 9.

Chenhong Xujing, "Guanyu Xiamenshi guoqi Gaige de jiaocha" (Research on the reform of State enterprises in the city of Xiamen), in Guoyou zichan guanli, n4, 1999, 1999, pp. 52-4. 
Chen Yongzhong, Wang Junbian and Pei Houdong, "Daxing guoyou qiye gaige yu fazhan de chenggong fanlie. Sichuan Changhongtizhi zhuanxing gean kaocha" (Reform of the major State enterprises and a successful example. A case study of the Changhong group in Sichuan province), in Jingjin Yanjiu Cankao, n 22, 1999, pp. 22-36

Ding X. L., "The Illicit Asset Stripping of Chinese State Firms", in The China Journal, n ${ }^{\circ} 43$, January 2000, pp. 1-28.

Dong Ying, "Shandong Zhucheng gufen hezuozhi qiye yanshi fenxi" (an analysis of the system of cooperative stockholding in the city of Zhucheng in Shandong province), in Gongye Jingji yanjiu, n¹1, 1999, pp. 5 - 11.

Duckett Jane, The Entrepreneurial State in China. Real Estate and Commerce Departments in Reform-Era Tianjin, London, Routledge, 1998, 264 pp.

Evans Peter, Embedded Autonomy. States \& Industrial Transformation, Princeton, Princeton University Press, 1995, 323 pp.

Fields Karl J., Enterprise and the State in Korea and Taiwan, Cornell, Cornell University Press, 1995, 269 pp.

Freund Elizabeth M., The Public Sector under Reform: Corporatizing China's State Enterprises, Hong Kong, Polytechnic University, 6/7 June 1997, 1997, 37 pp.

Granick David, Chinese State Enterprises, Chicago, University of Chicago Press, 1990.

Haggard Stephan and Kaufman Robert R., The Political Economy of Democratic Transitions, Princeton, Princeton University Press, 1995, 391 pp.

He Qinglian, Zhongguo de xianjing (China's Pitfall), Hong Kong, Mingjing Chubanshe, $1998,410 \mathrm{pp}$. 
Hirschman Alfred. O., Exit, Voice and Loyalty, Cambridge Mass., Harvard University Press, 1970, 162 pp.

Huchet Jean-François, "4\% Unemployment in China?", in China Perspectives,, $\mathrm{n}^{\circ} 15$, January-February 1998, pp. 68-9.

Huchet Jean-François, "The 15th Congress and the Reform of Ownership. A Decisive Stage for Chinese State Enterprises", in China Perspectives, $\mathrm{n}^{\circ} 14$, November-December 1997 , pp. 14-25.

Huchet Jean-François, "Concentration and Emergence of Corporate Groups in Chinese Industry", in China Perspectives, n²3, May-June 1999.

Huchet Jean-François, Transferts internationaux de technologie et industrialisation tardive: le cas de l'industrie électronique en République Populaire de Chine, PhD, [International Technology Transfers and Late Industrialisation. The Case of the Electronics Industry in the People's Republic of China] Université de Rennes I, 1993, pp. 635.

Huchet Jean-François \& Xavier Richet, “ Reconversion industrielle en Chine : l'entreprise Changhong Electronic Group, Mianyang, Sechuan " ["Industrial Reconversion in China. The Changhong Electronic Group, Mianyang, Sechuan"], Conversion, n 5, May 2000, p.19-24

Hussain Athar and Chen Jian, Political Economy of Chinese Corporate Groups, paper presented at the international conference, "The Emergence and the Structuring of Corporate Groups in P. R. of China: an International Perspective", Hong Kong, November 04 - 05th, 1999. Jefferson Gary H., Are China's Rural Enterprises Outperforming State-Owned Enterprises?, Symposium on Economic Transition in China, July 1993, Haikou, China, 1993. Jefferson Gary H., Rawski Thomas G. and Zheng Yuxin, Institutional Change and 
Industrial Innovation in Transitional Economies, Washington D. C., Research Paper Series, World Bank, 1994, 25 pp.

Jensen Michael C. and Meckling W. H., "Theory of the Firm, Managerial Behavior, Agency Costs and Ownership Structure", in Journal of Financial Economics, n³, October 1976, 1976, pp. 305-60.

Jensen Michael C., "The Modern Industrial Revolution, Exit, and the Failure of Internal Control Systems", in Chew D. H. (ed.), Studies in International Corporate Finance and Governance Systems. A Comparaison of the U.S., Japan, \& Europe, Oxford, Oxford University Press, 1997, pp. 18-37.

Kejizu Shanghaishi guoyouzichan guanli moshi yanjiu, "Shanghai shi guoyou zichanguanli moshi zhong de lingkong xitong", in Zhongguo Gongye Jingji, n³, 1999, 1999, pp. $19-24$.

Kennedy Scott, "The Stone Group: State Client or Market Pathbreaker?", in The China Quarterly, n¹52, December 1997, pp. 746-77.

Kwong Julia, The Political Economy of Corruption in China, Armonk, M. E. Sharpe, 1997, 175 pp.

Lardy Nicholas R., China's Unfinished Economic Revolution, Washington DC., Brookings Institution Press, 1998, 304 pp.

Lardy Nicolas R., "Fiscal sustainability: between a rock and a hard place", in China Economic Quarterly, ํ2, 2000, 2000, pp. 36-41.

Lee Ching Kwan, "From Organized Dependence to Disorganized Despotism: Changing Labour Regimes in Chinese Factories", in The China Quarterly, n¹57, March 1999, pp. 44-71. 
Lei Yingquan, Huang Xingguo, Hu Yuqing and Ren Zhiqin, "Dui Sichuansheng qiye guoyou zichan linke guanli youguan qingkuangde yanjiubaogao" (Research report on the situation in the management and control of State assets in Sichuan province), in Guoyou Zichan Guanli, nº , pp. 50-1.

Lemoine Françoise, FDI and the Opening Up of China's Economy, Paris, CEPII, Document de travail [Working paper], 2000, 88 pp.

Leung Trini W. Y., "S'organiser pour défendre ses droits; Contestations ouvrières en Chine dans les années 1990" [Organising to Defend One's Rights. Worker Protests in China in the 1990s], in Perspectives Chinoises, nº48, juillet / août [July-August] 1998, pp. 6 - 23.

Lin Cyril, Corporate Governance in China, paper presented at the international conference, "Corporate Governance of State-Owned Enterprises in China", OECD, Asian Development Bank, and Development Centre of the State Council of PRC, Beijing,, 18-19 January $2000,88 \mathrm{pp}$.

Liu Binyan and Link Perry, "A Great Leap Backward?", in The New York Review of Books, XLV, nº 15, October 8, pp. 19 - 23.

Lu Zhongyuan, "Ruhe fangzhi guoyou zichan yingyun jigou biancheng fanpai gongsi. Shanghai, Wuhan, Shenzhen de shixian ji qishi (How to prevent institutions in charge of State assets from becoming buraucratised companies)", in Zhongguo gongye jingji, nº $, 1999,1999$, pp. $18-20$

Ma Rengui, "Guozi guanli tizhi gaige de youyi tansuo. Nanning shi zujianguozi jingying gongsi qingkuang de diaocha" (An exploration of the advantages of the reform of the system of State asset management. An enquiry into the situation of companies managing State assets by the 
city of Nanning), in Guoyou Zichan guanli, n³, 1999, pp. 63 - 64.

McNally Cristopher, "Shanghai's Way Forward. A Prelude to China's Next Stage of Enterprise Reforms", in China Perspectives, n ${ }^{14}$, November / December 1997, pp. 33-9.

Maxfield Sylvia and Schneider Ben Ross (ed.), Business and the State in Developing Countries, Ithaca, Cornell University Press, 1997, 348 pp.

Nee V., "Organisational Dynamics of Market Transition: Hybrid Forms, Property Rights and Mixed Economy in China", in Administrative Science Quarterly, n 37, 1992, pp. 1-27.

North Douglass C., Institutions, Institutional Change and Economic Performance, Cambridge, Cambridge University Press, 1990, 152 pp.

O'Brien K.J., "Bargaining Sucess of Chinese Factories", in The China Quarterly, n 132 , December 1992, pp. 1086-100.

OECD, Reforming China's Enterprises, Paris, OECD, 2000, 130 pp.

Oi Jean, "The Evolution of Local State Corporatism", in Walder A. (ed.), Zouping in Transition, Cambridge Mass, Harvard University Press, 1998, pp. 35-61.

Oi Jean C., "The Role of the Local State in China's Transitional Economy", in The China Quarterly, December, $\mathrm{n}^{\circ}$ 144, China's Transitional Economy, 1995, pp. 1132-49.

Orrù Marco, Biggart Nicole Woolsey and Hamilton Gary G., The Economic Organization of East Asian Capitalism, Thousand Oaks, Sage Publications, 1997, 426 pp.

Putterman Louis, "The Role of Ownership and Property Rights in China's Economic Transition", in The China Quarterly, December, n¹44, China's Transitional Economy, 1995, pp. 1047-64.

Rawski Thomas G., "Implications of China's Reform Experience", in The China 
Quarterly, December, $n^{\circ}$ 144, China's Transitional Economy, 1995, pp. 1150-73.

Richet Xavier., Les économies Est européenne: crise et transition, [Eastern European Economies: Crisis and Transition] Paris, Arman Colin, 1992.

Riskin Carl, China's Political Economy. The Quest for Develoment since 1949, Oxford, Oxford University Press, 1987, 418 pp.

Sargeson Sally and Zhang Jian, "Reassessing the Role of the Local State: a Case Study of Local Goverment Interventions in Property Rights Reform in a Hangzhou Distric", in The China Journal, n²42, July 1999, pp. 77-99.

Shirk Susan L., The Political Logic of Economic Reform in China, Berkeley, University of California Press, 1993, 399 pp.

Stark David, "Recombinant Property in East European Capitalism", in Grabher G. and Stark D. (ed.), Restructuring Networks in Post-Socialism, Oxford, Oxford University Press, 1997, pp. $36-69$.

Steinfeld Edward S., Forging Reform in China. The Fate of State-Owned Industry, Cambridge, Cambridge University Press, 1998, 300 pp.

Tung Ricky, "Possible Development of Mainland China's Private Enterprises", in Issues and Studies, vol. 33, nº, June 1997.

Unger Jonathan and Chan Anita, "Inheritors of the Boom: Private Enterprise and the Role of Local Government in a Rural South China Township", in The China Journal, n²4, July 1999, pp. $45-74$.

Wade Robert, Governing the Market. Economic Theory and the Role of Government in East Asian Industrialisation, Princeton, Princeton University Press, 1990, 438 pp. 
Walder Andrew, "Urban Industrial Workers: Some Observations on the 1980's", in Rosenbaum A. L. (ed.), State and Society in China: the Consequence of Reforms, Boulder, Westview Press, 1992, pp. 103-20.

Walder Andrew G., "China's Transitional Economy: Interpreting its Significance", in The China Quarterly, December, n 144, China's Transitional Economy, pp. 963-79.

Wang Hua., Xavier Richet and Wei Wang, Foreign "Direct Investment in the Chinese Automotive Industry: Country of Origin Effects" Third EACES Paris Workshop, Marne la Vallée University, June 2000, mimeo, 14 pp.

Weitzman M. L. and Xu Chenggang, Chinese Township Village Enterprises as Vaguely Defined Co-operatives, London, Development Economics Research Programme, London School of Economics, 1993.

White Gordon, Howell Jude and Shang Xiaoyuan, In Search of Civil Society Market Reform and Social Change in Contemporary China, Oxford, Clarendon Press Oxford University Press, 1996, 241 pp.

White III Lynn T., Unstately Power. Volume I: Local Causes of China's Economic Reforms, Armonk, M. E. Sharpe, 1998, 521 pp.

Williamson Oliver E., The Mechanism of Governance, Oxford, Oxford University Press, 1996, 429 pp.

Woo Wing T., "Why China Grew?", in Boone P., Gomulka S. and Layard R. (ed.), Emerging from Communism. Lessons from Russia, China and Eastern Europe, Cambridge, The MIT Press, 1998.

Xu Qing, "Dangqian Zhiyue Ningxia Guoyou Zhongxiao qiye gaizhi nandian wenti 
youxi" (Analysis of problems in the reform of the system of small State enterprises in Ningxia province), in Ningxia Shihuikexue, n³, 1999, pp. 47-52.

Xu Xiaonian and Wang Yan, Ownership Structure, Corporate Governance and Corporate Performance, World Bank, Washington D.C., ronéo, 1997, 52 pp.

Zhao Minghua and Nichols Theo, "Management Control of Labour in State-Owned Enterprises: Cases from the Textile Industry", in The China Journal, n 36, July 1996, pp. 1-24. Zhongguo shehuikexueyuan gongyejingji yanjiusuo, Zhongguo gongye fazhan baogao 1997 (Report on industrial development in China, 1997), Beijing, Jingji guanli chubanshi, 1997. Zhu Delin and Hu Haiou, Zhongguo de huiheise jingrong (Black and Grey Financial Market in China), Changshu, Lixinhuiji chubanshe, 1997, 227 pp.

Zong Han, "Gufen hezuozhi de fazhan ji qi jiaojian" (The Development of Cooperative Shareholding), in Zhongguo Gongye Jingji, n², 2000, pp. 9 - 12. 